\title{
OVER OPRICHTING EN BESTUUR VAN TRUSTS.
}

\author{
DOOR ARTHUR T. HADLEY, \\ President van de Universiteit te Yale. $\left.{ }^{1}\right)$.
}

In het jaar 1898 werden in de Vereenigde Staten een antal nieuwe naamlooze vennootschappen, ontstaan uit de vereeniging (consolidatie) van verschillende industrieele ondernemingen, opgericht. Toen het bekeud werd, dat zij te zamen over een kapitaal van meer dan 900 millioen dollars beschikten, wekte dit feit de algemeene verbazing. In de eerste maanden van 1899 makkte deze beweging verderen voortgang en werd een aantal nieuwe maatschappijen van deuzelfden aard opgericht, met een gezameulijk kapitaal van 3$\rfloor 00$ millioen dollars of meer dan driemaal zooveel als iu het onmiddelijk voorafgannde jaar. ${ }^{2}$ )

Het valt niet gemakkelijk zich een voorstelling te maken van de grootte dezer beweging. Nooit heeft zich, noch op de Engelsche noch op de Amerikaansche markt, zulk een enorme en plotselinge overdracht van kapitaal voorgedaan. Meu vergelijke deze beweging met de consolidatie der spoorwegen. In het jaar 1887 (in welk jaar vele nieuwe spoorwegen gebouwd werden) kunuen ongeveer 700 millioen dollars zijn bijeengebracht voor den bouw van 13.000 Engelsche mijlen spoorweg.

1) Hoewel in den regel door ons geen vertaalde stukken worden geplaatst, hebben wij gemeend voor de hier volgende verhandeling van Prof. Hadley, oorspronkelijk in Scribner's Magazine voorkomende, eene uitzondering te mogen maken, aangezien daarin, door een bekwaam schrijver die midden in de beweging leeft, een onderwerp van groot actueel belang wordt behandeld.

Aan het slot (bladz. 115) heeft de vertaler eenige opmerkingen van zijn eigen hand toegevoegd.

DE Redactie.

${ }^{2}$ ) Eene volledige opgave geeft «The Chronicle» van 8 Juli 1899 , no 1770 . 
In de geheele periode, loopende van 1879-1882, toen het mijlental der spoorwegen zoo sterk werd uitgebreid, kan het geheele bedrag aan uitgegeven spoorwegwaarden niet zoo groot zijn geweest als het bedrag aan industrieele waardeu, in het eerste halfjaar 1899 uitgegeven. Onder deze omstandigheden wordt de quaestie van consolidatie van industrieele ondervemingen er eene van overwegend belang.

De volgende vragen doen zich bij ons op. Is deze bereging voorbijgaand of blijvend? Hoever zal zij zich waarschijnlijk uitstrekken? Welke grenzen (commerciëele of wettelijke) zullen haar worden gesteld? Hebben de socialisten gelijk met hunne bewering, dat eene nieuwe phase wordt bereikt op den weg die leidt tot de eindelijke "Verstaatlichung" der nijverheid? Deze vragen dringen zich bij ons op en moeten worden beantwoord.

Veilig kan men beweren dat de beweging niet lang op deze wijze kan voortgaan. Enkele van de industrieele uitgiften mogen eene belegging van nieuw kapitaal vertegenwoordigen, een grooter aantal zijn ontstaan uit de conversie van oud kapitaal. Natuurlijk is deze conversie begrensd en kan zij alleen zoolang geschieden, totdat alle of bijna alle ondernemingen is een bepaalden tak van nijverheid zijn geconsolideerd. Het is in hooge mate twijfelachtig of van de 3000 millioen dollars industrieele waarden, in het eerste halfjaar 1899 uitgegeven, 1000 millioen of zelfs 500 millioen werkelijk nieuw kapitaal in de verschillende takken van nijverheid gestoken, vertegenwoordigen. Vergeleken net de veranderiug der waarden in de ondernemingen belegd, is de vooruitgang van het bedrijf zelf niet van overwegend beling. Bij de meeste ondernemingen staat op den voorgrond de wensch een markt te creeëren voor de industrieele waarden, terwijl de zucht oon verbeteringen in het bedrijf an te brengen en door de consolidatie intensiever te produceeren pas in de tweede plaats in anmerking komt.

Onderzoeken wij welk verschil bestaat tusschen deze beide redenen en hoe zij op het tegenwoordige oogenblik hun invloed doen gevoelen.

Iemand die zijn geld belegt in een onderneming van nijverheid wordt geleid door twee overwegingeu. In de eerste plaats wenscht hij eene zoo hoog mogelijke reute van ziju kapitaal 
te maken. In de tweede plaats wenscht hij zijn geld uit de zaak te kunuen terugnemen wanneer hij het zelf noodig heeft en zoo mogelijk dan meer geld te ontvangen dan hij in de zaak gestoken heeft. De onderneming moet voordeelig werken en de waarden moeten gemakkélijk gerealiseerd kunnen worden. tot op zekere hoogte vallen deze beide overwegingen zamen. Een fonds dat ruime en regelnatige divideuden gedurende een reeks van jaren heeft opgeleverd, wordt langzamerhand op de locale markt goed bekend en kan, ingeval de eigenaar tot verkoop wenselit over te gaan, met betrekkelijk kleine opoffering van ziju kaut worden gerealiseerd. Maar dit is slechts betrekkelijk en tot zekere hoogte juist. Enkele oorzaken die de waarden vau eene bepaalde onderneming begeerlijk maken voor een individueelen bezitter, leiden er toe dat die waarden minder gemakkelijk ziju van de hand te doen. Fen locale (plaatselijke) onderueming aan iemand's dagelijksch toezicht onderworpen en wier détails hij uit ondervinding kent, moge hem een veilige belegging voor zijn kapitaal bieden, voor anderen kunnen de warden van bedoelde onderneming mogelijk minder begeerlijk zijn. De waarden zijn dan veilig om te bezitten unar incourant en moeilijk te verkoopen. De persoonlijke en grondige kenuis die den bezitter beveiligt tegen gebeurlijkheden, kan voor andere houders van dezelfde waarden een gevaar uitmaken. De groote meerderheid der beleggers houdt zich op een afstand en als gevolg hiervan bestaat er gewoonlijk geene evenredigheid tusschen de markt-waarde van de aandeelen en den interest, dien zij den houders opleveren.

Een groot aantal bedrijven in de Vereenigde Staten zijn gebonden gebleven aan deze platselijke belemmering. Wanneer wij de geschiedenis der industrieele waarden en die der spoorwegwaarden vergelijken, worden wij getroffen door de beperkte markt der eerstgenoemde. Goede spoorwegwaarden vonden allerwege koopers. Was de prijs der spoorwegaaudeelen bepaald laag in verhouding van de opbrengst, dan was het omdat men het opbrengstvermogen van den weg wantrouwde. Zelfs kleine, onbelangrijke spoorwegen genoten soms een reputatie over het geheele land voor veilige belegging De vraag voor waarden van spoorwegen, in Iowa gelegen, kwam niet uit dien Staat of een bepaald gedeelte van ditn Staat. Maar 
de vrag voor waarden van een bepaalde fabriek in Iowa was zuiver plaatselijk. Het bedrijf werd niet door het publiek gecoutrôleerd en de waarden konden alleen eene veilige belegging vormen voor hen die de gelegenheid hadden het bedrijf meer van nabij te zien en met de "ins nnd outs " bekend te worden.

Maar werd een bedrijf geconsolideerd over het gansche gebied der Vereenigde Staten, dan veranderde de toestand spoedig. Een grooter deel van het beleggend publiek was bereid de waardeu te koopen van de "American Sugar Refineries Company" of van de "American Tobacco Company" dan bereid zoude geweest zijn een gedeelte van zijn vermogen te beleggen in de verschillende ondernemingen, waaruit de combinatie was samengesteld. De groote uitgebreidheid van de organisatie vergunde deu individueelen houder der waarden gebruik te maken van de ruimere en minder wisselvallige gelegenheid om zijne waarden te realiseeren dan hij zoude gehad hebben ware elk bedrijf op zich zelf blijven staan. Dikwijls, hoewel niet altijd, was het hem ook mogelijk een beter prijs te bedingen. Hoewel deze overwegingen bij de oprichting der eerste "trusts" niet altijd op den voorgrond stonden, waren de oprichters handig genoeg hun voordeel te doen met deze bijkomende omstandigheil. Behalve de bezuiniging in exploitatiekosten, als aanleidende oorzaak van de combinaties opgegeven, trad weldra de overweging oin de ait te geven warden gemakkelijk en tegen hoogen prijs van de haud te doen, als van njet minder belang op den voorgrond.

Behalve deze volkomen gewettigde toeneming van industrieele waarden, die haar groud vindt in het feit dat de waarden gemakkelijker en onder een grooter publiek geplaatst kunuen worden, kwam er een toeneming tengevolge van minder gewettigde redenen, namelijk van het gemak dat zij wel ingelichten tot manipulatie der koersen aanbieden. Ook in beleggingen is er een mode evenals in alle zakeu. Een groot gedeelte van het publiek koopt wat zijn buurman koopt. Somtijds land; somtijds spoorwegwaarden; tegeuwoordig industrieele waarden. In tijden van voorspoed, inet neiging tot opsehroeving, rijzen ook de speculatieve fondsen gemakkelijk. Heeft men eenmaal gekocht dan doet het aangenaam aan zijn bezit in waarde te zien stijgen en koopt men meer. Diegenen die met het bestuur in verbin- 
ding staan, zien hunne kans schoon om hun berit geheel of gedeeltelijk met winst te realiseeren. Voordat de onvermijdelijke "krach" komt, hebben zij hun bezit opgeruind en de nietingelichte betaalt het gelag. Voor de crisis van 1873 boden de spoorwegfondsen alle gelegenheid tot dit spel maar vrachtverhoudingen en boekhouding der spoorwegen zijn tegenwoordig aan zulke strenge contrôle van het publiek onderworpen, dat de kansen daarbij niet meer zoo schoon staan als vijf en twintig jaar geleden. En, wat van nog meer belang is, door harde lessen en bittere ondervinding geleerd, is het beleggend publiek angstig geworden voor oneerlijk beheerde spoorwegen. De speculant, die industrieele waarden wil manipuleeren, ontmoet minder bezwaren op zijn weg De regeering oefent geen voldoende toezicht uit; het publiek heeft nog niet geleerd het kaf vau het koren te scheiden.

Industrieele waarden te koopen eenvoudig omdat die fondsen in de mode zijn, is natuarlijk een werk van dwazen en moet hieraan een einde komen. Ontdekken de beleggers, dat het uitgedachte systeem van eerste en tweede preferente aandeelen een zeer gemakkelijk middel is om hen aan genade en ongenade van een oneerlijk bestuur over te leveren, dan zullen wij waarschijnlijk een schijnbaren stilstand in den schielijken groei van industrieele consolidaties zien. Ben reactie is niet onmogelijk, wanneer - gelijk veelal geschiedt — de onberedeneerde voorliefde van het publiek voor eene bepaalde belegging plaats maakt voor een even onberedeneerden afkeer van alle mogelijke ondernemingen, gewettigd of niet, in denzelfden vorm opgericht. Zulk een reactie is niet onbekend in de economische geschiedenis der negentiende eeuw. Overspeculatie in Engelsche spoorwegen in 1844, in Amerikaansche spoorwegwaarden in 1873 , in warrants en ceelen in 1881 had tengevolge dat in de jaren, onmiddellijk op die overspeoulatie volgende, geene uitgifte van eenige beteekenis plaats vond van waarden die eerst een veelbelovenden en belangrijken vorm van belegging of speculatie uitmaakten.

Veilig kan men voorspellen dat de toeneming van groote industrieele combinaties in de toekomst minder snel zal geschiedeu dan tot heden. Consolidaties, die alleen verkoop van hare wardeu en bedrog van het beleggend publiek ten doel 
liadden, zullen verdwijnen. Maar een zeer groot aantal, die op solide basis gegrondvest werden, zullen blijven bestaan en deze zullen waarschijnlijk over twintig jaar van meer belang zijn dan nu. Naarmate de wereld voortschrijdt, zal de bezuiniging in de productie bij groote ondernemingeu beter begrepen worden. De beweging in deze richting bepaalt zich niet tot de Vereenigde Staten alleen. Evengoed wordt die beweging gevoeld in Engeland en zoo mogelijk nog sterker in Duitschland. Indien omtrent deze industrieele consolidaties in Europa miuder wordt gesproken dau omtrent die in Amerika, dan is dit alleen het geval omdat zij rustiger hun gang zijn gegaan en niet omdat zij minder in anntal of van minder belang zijn. Zij zijn minder op den voorgrond getreden, omdat zij geene waarden te verkoopen hadden en zoodoende verkeert het publiek omtrent hen meer in onwetendheid. Dat zij in het duister werkten heeft, wel verre vau schade te doen aan het uitoefenen van hun bedrijf, eerder tot vergrooting van hunne macht geleid.

De aard der bezuiniging die door deze combinaties kan worden verkregen, is reeds door zoovele schrijvers over dit onderwerp in het licht gesteld, dat wij dit punt slechts even behoeven aan te roeren. Tweeërlei voordeelen zijn aan de consolidaties verbonden. In de eerste plaats worden door de vereeniging van alle mededingende fabrieken vele onnoodige uitgaven ter plaatsing van het product bespaard. Onder de werking van het vroegere systeem zijn deze onkosten zeer hoog. Wen aantal verkoopplaatsen moeten worden in stand gehouden en drukken de onkosteu-rekening zwaar. Ter wille van de concurrentie moet druk geadverteerd worden, dikwijls een onnoodige en zeer onvoordeelige uitgaaf. De goederen moeten door de onafhankelijke producenten, per spnorweg of per wagen, worden afgeleverd hetgeen menigmaal meer kost dan de beter geregelde verzendingen van een groot lichaam. Al deze nadeelen kunneu na consolidatie vermeden worden. In de tweede plaats heeft een geconsolideerde maatschappij groote voordeelen boven andere doordat zij in de mogelijkheid is de productie aan het verbruik aan te passen. Waar verschillende ondernemingen met uitgebreide fabrieken concurreeren en niet geheel op de hoogte van elkanders productievermogen zijn, bestaat alle kans dat jaren van te uitgebreide voortbrenging en jaren van 
schaarschte met elkander zullen afwisselen. Een afwisseling niet minder schadelijk voor de verbruikers en het publiek dan voor de onmiddelijk belanghebbendeu. Veel van deze nadeelen kunnen worden voorkomen door eene goed georganiseerde combinatie. Door de voortbrenging gelijkmatiger te verdeelen, kunnen de verbruikers geregeld worden voorzien van het artikel en de arbeiders geregeld aan het werk gehouden worden. De vastheid van prijs, een gevolg van de organisatie, is zulk een belangrijk voordeel voor het algemeen dat het publiek gaarne bereid zal zijn een ruime winst te verzekeren en te betalen aan hen, wier organiseerend talent zulke diensten heeft bewezen.

De verdedigers van industrieele consolidaties geven in het kort op bovengemelde wijze de ontzaglijke voordeelen van het stelsel weer. Het behoeft geen betoog dat het voor een gedeelte toekomstmuziek is, die wij hooren, en ons eerder de mogelijkhedeu van het stelsel worden geschetst dan de tot heden bereikte resultaten. Waar één onderneming deze resultaten heeft bereikt, staan vijf, misschien tien, andere die niet op dezelfde uitkomst kunnen wijzen. Tegen één combinatie die groote winsten heeft behaald door het publiek op goede en goedkoope wijze te voorzien, staan vele andere die beproefd hebben grove winsten te maken op verkeerde wijze en die te gronde zijn gegaan, na aan hunne aandeelhouders en het publiek belangrijke verliezen en schade te hebben berokkend.

Zoo lang echter als het voor een goed bestuurde consolidatie mogelijk is beter en zuiviger te werken dan mogelijk was onder vrije mededinging, zoolang zal de beweging in deze richting voortschrijden. Overal waar werkelijk eene bezuiniging kan worden verkregen; zullen beleggers hun voordeel doen met de hun geboden gelegenheid. Pogingen om hen hierin tegen te gaan, zullen waarschijnlijk ijdel blijken. Geen beter bewijs van de sterke neiging tot consolidatie dan het antal wetten die niet worden gehandhaafl en rechterlijke beslissingen, alle bedoelende den stroom te keeren.

Toeu de eerste spoorwegen werden gebouwd, verklaarde een groot gedeelte vau het publiek zich tegen het monopoliseeren van het vervoer dat hun werd verzekerd. Wetten werden gemaakt om den spoorweg vrij te maken en de baan open te stellen voor alle vervoerders, even als de publieke weg vrij 
gebruikt kan worden door alle eigenaars van vrachtwagens. Maar de voordeelen voortspruitende uit het feit dat slechts ééne mantschappij het recht had den treinenloop te regelen, waren zoo groot dat het publiek gedwongen werd zijn denkbeeld van vrijen weg op te geven. Toch bleef men aandringen dat de verschillende spoorwegen met elkander zonden concurreeren en werden verschillende wetten gemaakt om de oprichting van "pools" en vervoer-associaties te verbieden. Enkele vau deze pogingen bleken van den beginne af dood geboren kinderen te zijn; andere hebben het proces van consolidatie vau de mededingende ondernemingen verhaast, wardoor deze laatste buiten het bereik kwamen van de op hen toepasselijke wettelijke maatregelen; de enkele die werden gehandhaafd, deden veel $k$ waad en weinig goed. De meerderheid van de lieden die over dit punt nadachten, kwam tot de slotsom dat spoorwegen in zekeren zin een natuurlijk monopolie uitmaken en rangschikte spoorwegen, waterleiding- en gas-maatschappijen onder die bedrijuen, die ten behoeve van het publiek moeten worden geexploiteerd en aan de vrije mededinging behooren te worden onttrokken. Langzamerhand beginnen wij in te zien dat dezelfde mogelijkheid van bezuiniging, eerst gebleken in de bovengemelde ondernemingen, ook toegepast kan worden il de voortbrengings-nijverheid. De noodzakelijkheid van bezuiniging wordt gevoeld in alle ondernemingen die met groote machines enz. werken $\mathrm{Er}$ bestaat alle reden om te meenen dat de neiging tot consolidatie zich even onvermijdelijk zal doen gevoelen in de nijverheid als zij het in het vervoer heeft gedaan. In het eene geval even goed als in het andere mag men verwachten, dat wetten tegen "pools" oprichting van trusts zullen tengevolge hebben en dat wetten tegen trusts zullen leiden tot consolidatie.

Dit proces zal waarschijnlijk niet plotseling geschieden.

Er bestaan practische bezwaren tegen consolidaties en deze wegen neer dan de wettelijke. Een groote moeilijkheid is hierin gelegen, dat men zeer bezwaarlijk personen vindt geschikt om deze groote combinaties te beheeren en te besturen. Even als in een leger velen geschikt zijn voor kapitein, weinigen voor kolonel en slechts enkelen voldoende bekwaam om als generaal het opper-commando te voeren - zoo zijn er 
ook in nijverheids-oudernemingen een groot aantal lieden die eenige duizeuden dollars kuunen beheeren, weinigen die een millioen dollars kunnen beheeren en zeer enkelen die met goed succès vijftig millioen dollars kunnen administrateeren en productief maken. De hersenen van mannen, gewend aan een kalıne en rustige vervulling van hun taak als bestuurders, worlen alleen door het afmattende werk van zulk een reusachtig gecentraliseerde administratie zoo- gepijnigd, dat slechts enkelen in staat zijn zulk een last te dragen

En dit is nog niet alles waarmede rekening valt te houden. De bestuurders van een gemonopoliseerde nijverheid bebben een grooter aautal quaesties te beslissen dan zich ooit onder het oude systeem van vrije mededinging aan hen voordeden. Waar verschillende ondernemingen dezelfden soort goederen produceeren, wordt de verkoopprijs voor een groot gedeelte door de onderlinge concurrentie bepald. Elke onderneming moet c. p. tegen den marktprijs verkoopen. De beheerder bepaalt zijn aandacht tot bezuiniging op de productie om in staat te ziju winst te maken op prijzen die voor zijn mededinger misschien verliesgevend ziju. Maar worden al deze ondernemingen in één hand geconsolideerd, dan wordt de macht orn de prijzen van het product vast te stellen, belangrijk grooter. De beheerder vraagt niet meer tegen welken prijs zijne concurrenten verkoopen; hij vraagt zich alleen af, welken prijs de vragers geneigd zijn te betalen en hoe ver hij kau gaan. On deze vraag goed te beantwoorden, moet hij zoowel met de toekomstige uitbreiding dier nijverheid als met den tegenwoordigen toestand rekening houden. De autocratische macht door het ontbreken van mededinging in zijne handen gesteld, kan hem in de verleiding brengen de prijzen op te voeren tot eene hoogte, schadelijk voor het publiek en schadelijk voor de duurzame belangen der consolidatie. Vroegere ondervinding met industrieele consolidaties opgedaan, wijst helder aan dat zeer weinige manuen in staat zijn weerstand te bieden aan deze verleiding en de macht die het moderne systeem hun in handen geeft, goed te gebruiken.

De naam "trust," in het spraakgebruik aan al deze groote combinaties van kapitaal gegeven, ontstond toevallig. De naam "trust" (toevertrouwd goed) is goed gekozen. De beheerders 
van elke consolidatie, hetzij ontstaan uit speciale overeenkomsten, eeu eigenlijk trust-contract, hetzij uit eene combinatie van ondernemingen oefenen een macht uit, waardoor de belangen van het publiek of gebaat of geschaad kunnen worden en die vergeleken kan worden met de macht van een "trustee." Men heeft gezegd dat alle eigeudom, ruim gesproken, den eigenaar slechts ten bate van het publiek wordt toevertrouwd. Maar daar waar sterke concurrentie heerscht, is de macht om hooge prijzen op te leggen orij beperkt en de kans gering dat het eigendomsrecht wordt misbruikt. Alleen bij de groote combinaties, met hun willekeurige macht ten goede of ten kwade, wordt werkelijk het denkbeeld van een macht, door de gemeenschap in handen van deze ondernemers gelegd en hun ter uitoefening toevertrouwd, verwezenlijkt. Zeer moeilijk is het ook hier wettelijke maatregelen te nemen die de uitvoering van deze toevertrouwde macht ten bate van de gemeenschap verzekeren De kennis noodig om een "trust" te regelen is slechts te verkrijgeu na een lange studie van wettelijke matregelen en economischen invloed. Men kan geen wet maken die het goede gebruik van die willekeurige macht toelaat en het misbruik verbiedt. Maar mogelijk is het de bestrande wetten te verbeteren in meer dan eene richting, waardoor het proces van gezonde ontwikkeling verhaast zal worden. Tot dusver zijn de meeste wettelijke maatreg(len ondoordacht geweest. Wij hebben getracht het onvermijdelijke te keeren en het gevolg is alleen geweest dat wij het gebruik van slinksche en kortzichtige middelen hebben aangemoedigd in stede van de "irusts" te dwingen openlijk te werken.

Om in het vervolg de zaak in het goede spoor te brengen, moeten drie punten op den voorgroud staan.

10. Grooter verantwoordelijk van het bestuur (directie en commissarissen).

In alle gevallen waar het bestuur werkt alleen ten eigen bate en geen rekening houdt met de belangen van de houders van waarden ten laste der maatschappij of zelfs de duurzane belangen van die beleggers in de waagschaal stelt, zullen de fouten en misbruiken van industrieele combinaties het sterkst uitkomen en wordt de mogelijkheid van eenige verbetering tot een minimum teruggebracht. 
In de eerste plaats belet liet feit, dat liet bestuur geen rekening houdt met de belangen der beleggers, de leden van dat hestuur te erkennen dat zij verplichtingen hebben tegenover het publiek. Zaken doen is voor hen een spel hetwelk zij naar vaste regels spelen. $\mathrm{Zij}$ offeren de personen, ten wier behoeve zij spelen, op om zelf het spel te winnen. Dit onjuiste denkbeeld, dat aan hunne handelingen ten grondslag ligt, belet hen ook in te zien hoe zij de zaken, aan wier hoofd zij gesteld zijn, moeten besturen.

In de tweede plaats is het in hooge inate onwarschijnlijk, dat de tijdelijke belangen die het bestuur er toe brengen de markt te manipuleeren, samenvallen met de werkelijke belangen vau het publick, hetzij arbeiders hetzij consumenten. De belangen van den speculant kunuen mogelijk worden gebat door de prijsverschillen die tengevolge der consolidatie behooren te wordeu vermeden. Indieu een bedrijf als dat der Standard Oil Corupany wordt gedreven met het oog op de duurzame belangen van het publiek, zal meu meestal bemerken dat de prijzen betrekkelijk laag en standvastig blijven en dat de arbeiders in het bedrijf geregeld werk vinden. Maar in andere gevallen, warin de zaken door de bestuurders ziju gemanipuleerd, zijn de einduitkomsten juist tegenovergesteld geweest.

Ten laatste - misschien het gewichtigste van de besproken punten - indien het bestuur wordt vrijgelaten geld te verdienen onafhaukelijk van de werkelijke belangen van den belegger en den consument beiden, wordt de opvoedende kracht, die een gevolg behoort te ziju van succès of tegenspoed in zaken, ten eenenmale gemist. Wanneer iemand een zaak bestuurt in het volle gevoel van zijne verantwoordelijkheid tegen over hen die hun kapitaal in zijue onderneming hebben belegd, beteekent de mislukking om de belangen van het publiek goed le behartigen op den langen duur het opgeven van zijn eigen doel en eerzucht. Mislukt de onderneming slechts gedeeltelijk, dan zal de ondervinding hem leeren hoe het in het vervolg beter te doen. Mislukt de zaak geheel, dan zal hij zijn plaats aan eeu auder moeten afstaan. Maar heeft hij slechts een tijdelijke speculatie in het bedrijf gezien, de gelegenheid om waardeu te koopen tegen prijzen gedrukt tengevolge van valsche berichten, heeft hij die waarden slechts tijdelijk ge- 
houden en ze bij rijzing onder valsche voorweudsels aan bedrogen geldbeleggers verkocht, dan trekt hij niet de minste nuttige les uit het beheer van de onderneming. Dezelfde mis slagen kunnen dan herhaaldelijk gemaakt worden ouder een telkens afwisselend bestuur. De absolute voorwaarden van een radicale en afdoende verbetering van bestaande misbruikeu zijn een strenger toezicht bij de oprichting van nieuwe maatschappijen, verplichte openbaarmaking van balansen, erkenning wettelijk en zedelijk - van de aansprakelijkheid van beheerders, dje onjuiste verslagen aan de aandeelhouders hebben overgelegd.

20. Verandering en wijziging in de wettelijke bepalingen omtrent het arbeidscontract. Hier staan wij op meer twijfelachtigen bodem. Het is gemakkelijk aan te toonen dat de tegenwoordige verhouding tusschen groote corparaties en hunne geëmployeerden niet afdoende geregeld is. Het valt niet gemakkelijk te zeggen wat gedaan moet worden oin die verhouding te verbeteren. Zooals de toestand nu is, kan een werkstaking, op lossen grond begonnen, het verkeer en de productie van de geheele gemeenschap op losse schroeven zetten. De uatuurlijke oplossing uit genoemde moeilijkheid schijnt arbitrage dwingend te maken. Maar in de praktijk heeft dwang-arbitrage niet zoo goed gewerkt als inen wel zoude gewenscht hebben. Waarsehijnlijk moeten in dit opzicht veranderingen in de wetgeving langzamerhand worden aangebracht. Aan de verplichting ran eene consolidatie om geregeld hare diensten aan het algemeen te bewijzen moet worden verbouden een nauwkeuriger omschrijving van de verplichtingen van den werkman in dit opzicht. Wat ook gedaan kan worden of niet bereikt kan worden tengevolge van wettelijke bepalingen, de gemeenschap moet leeren inzien dat zij die aan het hoofd staan van groote industrieele ondernemingen, niet alleen hun eigen of andermans kapitaal beheeren, maar in de eerste plaats leiders van de productie zijn; en de beheerder van zulk eene consolidatie, aan wieus nalatigheid het te wijten is, dat de productie tengevolge van werkstakingen belemmerd wordt, staat gelijk met een generaal, die begeerig om de voordeelen van zijn hoogen post te behouden, niet heeft belet, dat de vijaud zijn land binnentrekt en zijne legermacht insluit.

$3^{\circ}$ Grooter voorzichtigheid bij het opleggen van 
hooge inkomende rechten. Tot heden hebben wij den ondernemers in elken tak van bedrijf vrij wel overgelaten voor te stellen, welke rechten van de voortbrengselen der buitenlandsche concurreerende nijverheid moesten geheven worden. Wij hebben dit gedann wetende dat - werden bedoelde tarieven te hoog gesteld - de binnenlandsche mededinging van nieuwe ondernemingen de behaalde winsten tot een meer bescheiden schaal zoude terugbrengen. Gelijk van zelf spreekt, zijn misslagen begaan die groote ell onnoodige prijsschommelingen tengevolge hadden. Maar in den regel heeft binnenlandsche mededinging de eigenmachtige resultaten van de tarief-smeders binnen zekere bescheiden grenzen teruggebracht. Wordt echter alle binnenlandsche concurrentie opgeheven, dan is het gevaar ernstiger en meer van blijvenden aard. Het is niet wel mogelijk de tarief quaestie te behandelen zonder de grenzen van dit artikel te overschrijden. Maar wij mogen verklaren dat in alle bedrijven die geheel gemonopoliseerd zijn, het algemeen belang zal eischen dat, indièn de inkomende rechten hun prohibitief karakter behouden, de schatkist een deel van de gemaakte winsten zal opeischen. In het feit dat eene nijverheid tot deze organisatie is gekomen, ligt opgesloten dat zij tot vollen wasdom is opgegroeid. Blijft zij een prolibitief tarief op hare producten van den staat verlangen, dan ligt het vermoeden voor de hand, dat zij tracht ten koste van den verbruiker zich ongewettigde winsten te verzekeren.

In bovengemelde richting zullen de groote corporaties, naarmate zij min of meer het karakter vau monopolies beginnen aan te nemen, worden gebonden. Maar er blijft een moeilijker vraag ter beantwoording over, op welke vraag velen geneigd zijn een radicaal antwoord te geven. Waarom zal men toelaten dat dergelijke monopolies door particuliere maatschappijen worden uitgeoefend?

Mag men niet met vrij groote zekerheid aannemen dat dergelijke consolidaties een stap zijn in de richting van staatseigendom van alle industrieele ondernemingen? Staan wij niet aan den vooravond van een ernstige crisis waarin de definitieve strijd zal worden geleverd tusschen individualisme en socialisme, tusschen kapitaal en arbeid? 
Het is zeer wel mogelijk dat eeu aantal dezer ondernemingen binnen afzieubaren tijd staatseigendom zullen worden. In hooge mate onwaarschijulijk is het echter, dat deze neiging tot consolidatie de gevaren van een botsing tusschen individualisten en sooialisten zal vergrooten. Het gevolg zal zijn dat dit gevaar wordt verminderd doordat de quaestie van staatseigendom voor de groote meerderheid der burgers betrekkelijk onbelangrijk wordt. Men moge zich over deze meening verwonderen maar een aantal feiteu bevestigen haar. In den laatsten tijd heeft er, in verband met deze neiging tot consolidatie, tusschen particuliere en staatsexploitatie eene wisselwerking plats gevouden. Vroeger waren deze beide scherp van elkaar gescheiden : heden teu dage is hunne werking en methode niet meer zoo verschillend. De particuliere nijverheid kan weinig meer opleveren dan rente over het kapitaal in die nijverheid belegd. Hoogere winsten worden door de heftige mededinging op industrieel gebied belet. Exploiteeren Staat of gemeente een bedrijf, dan kumnen zij niet minder doen dan interest verdienen over de kapitalen, in dat bedrijf vastgelegd, daar de belastingbetalers scherp op de uitkomsten van het bedrijf toezien. De belasting-betalers zullen nooit genoegeu nemen met de exploitatie van een bedrijf, dat verlies oplevert en hunue lasten verzwaart. Het ligt nu voor de haud dat de verhouding van eeu consument tegenover eene particuliere onderneming die minder dan 4 pCt. betaalt, niet veel verschilt met zijne positie tegenover een "Staatsbetrieb" dat meer dan 3 pCt. moet betalen. Het verschil, van een finantieel standpunt bezien, is dus tot een minimum teruggebracht. En het is niet veel grooter als wij de zaak van een exploitatie-standpunt beschouwen. De beambten van een groote particuliere corporatie komen bijna nooit in directe aanraking met de aandeelhouders der vennootschap. Onze ambtenaren die het werk van staats- of gemeentebedrijf verrichten, komen bijna nooit meer in aanraking met de kiezers. De beambte trault niet meer zich bij een bepaalde groep van aandeel- of obligatie-houders angenaam te maken of bij die groep in de gunst te komen; de aubtenaar tracht niet meer in de guust te komen van een bepaalde groep "politicians." Den man, die het wel doet, wordt terecht verweten geen inzicht te hebben in de verplichtingeu, die 


\section{4}

zijne betrekking hem oplegt. Hoe meer het beginsel van werkelijke verdienste wordt toegepast, hoe meer de uitroering gelijk wordt. De aansprakelijkheid van particuliere beambten en ambtenaren brengt hen tot de toepassing van techuische bekwaamheid en van gezonden geest van zaken doen en tot veronachtzaming van machtige particuliere belangen. Onder deze omstandigheden wordt de aard van een goed bestuurd staats- of gemeente-bedrijf en die van een goed bestuurde particuliere onderneming zoo gelijk, dat het voor de meesten onzer betrekkelijk weinig versehil maakt of de leiding berust bij de vertegenwoordigers der kiezers of die der machtige financiers. Gevraagd wordt alleen, welke methode geeft de beste resultaten eu leidt tot de minste misbruiken.

Met vertrouwen zien wij den tijd komen waarin de vraag "staats- en gemeente-bedrijf of particuliere exploitatie vau iudustrieele ondernemingen" haar politiek belang zal verliezen en eenvoudig opgelost zal worden op economische gronden, als een handelszaak. Dan zullen economische redenen misschien leiden in eén geval tot staats- en gemeente-bedrijf en in een ander geval tot exploitatie door particulieren. Strijd zal blijven bestaan tusschen hen die meer geld hebben dan stemmen-aantal en die hun sfeer van commercieele werkzaamheden willen uitbreiden en heu die over meer stemmen dan kapitaal beschikken en die de sfeer van politieke werkzaamheid willen vergrooten. Maar de groote meerderheid van het volk, die beschikt over é́ne stem en over juist voldoende middelen om zich zelf en familie een voldoende bestaan te verzekeren zal waarschijnlijk door de oplossing van dit vraagstuk niet voldoende geïnteresseerd worden om met geweld het conflict te beslissen.

Resumeereude, komen wij tot de volgende conclusies.

In zooverre als de tegenwoordige neiging tot industrieele consolidatie haar oorsprong neemt in een speculatieve beweging on diverse waarden te verkoopen, bestaat er alle waarschijnlijkheid dat die beweging van kortstondigen duur zal ziju. In zooverre als het doel is bezuiniging in exploitatiekosten en kosten van verkoop enz., zal de beweging waarschijnlijk duurzaam zijn. Pogingen om deze neiging tot consolidatie door wettelijke mantregelen te keeren, zullen ijdel blijkeu. Zij waren het bij de consolidatie van het, vervoer en zullen het zijn bij 
de consolidatie van de industrie. De groei van deze ondernemingen geeft aan de beheerders eene willekeurige macht zoowel om het algemeen belang te schaden als den consumenten voordeelen te bezorgen. In dien zin wordt de uituefening van deze inacht aan de beheerders als het ware door de gemeenschap toevertrouwd. Voor een verstandige nitoefening dier macht kan inen niet door wetten zorg dragen; zij moet het gevolg zijn van een economische opvoeding die kan wordeu versterkt door een juist inzicht in de aansprakelijkheid, rustende op de beheerders. Naar mate dit proces van consolidatie en opvoeding verder voortschrijdt, begint het verschil in aard tusschen particuliere onderneming en staats- of gemeente-bedrijf te verdwijnen. De quaestie van staats-eigendom vau industrieele ondernemingen zal in stede van tot scherpen nationalen strijd aanleiding te geven (gelijk veleu op dit oogenblik nog verwachten) eerder van betrekkelijk ondergeschikt belang worden en warschijnlijk geheel van het politiek terrein verdwijnen.

In over-kapitalisatie der in den aanvang van 1899 opgerichtte consolidaties ligt een groot gevaar, voor aaudeelhouders en voor het publiek. Verschillende ondernemingen zijn overgekapitaliseerd en zelfs onder zeer gunstige omstandigheden zullen zij niet gemakkelijk een behoorlijke rente op dit kapitaal kunnen verdienen. Maar men moet niet vergeten, dat de over-kapitalisatie binnen zekere grenzen is gebleven, daar de consolidaties werden opgericht op grond van gegevens en ontvangsten uit de achter ons liggende magere jaren. Veel grooter zoude het gevaar worden, wanneer de groote ondernemingen werden opgericht in de vette jaren en gekapitaliseerd op de cijfers en buitengewoon schitterende ontvangsten uit een tijd van voorspoed. Ongemotiveerde koersverhoogingen in de industrieele waarden zouden een gevolg ziju van ongewoon hooge ontvangsten en berekende winsten. Gebiedend noodzakelijk is het darrom, dat de beheerders der groote industrieele corporaties ruime afschrijvingen voor waardevermindering van vast en vlotteud kapital doen geschieden en een reservekas vormen in de tegenwoordig zeer guustige tijden. Goed georganiseerd en goed bestuurd, kunven industrieële 
corporaties belaugrijke voordeelen op de wereldmarkt bedingen.

Daarvoor is noodig eeu geregelde productie en een beheer dat niet vervalt in de font de markt te overvoeren. In deze regeling der proluctie ligt voor een groot gedeelte de kracht der consolidaties. Komen de magere jaren en de tijden van tegenspoed, dan kuunen zij een uuttige rol spelen. Vroeger trachtte elke ondernemer in tijden van depressie eeu zon groot mogelijk gedeelte van de reeds verminderde vraag te bevredigen, vandaar demoralisatie in het bedrijf. Combineeren de ondernemingen zich, dan kau elke onderneming aan het werk gehouden worden, al wordt de vraag minder, en een gedeelte van de vraag op de markt bevredigen tegen loonenden prijs. Niets heeft meer bijgedragen tot de demoralisatie van de nijverheid dan te groote productie in tijden van voorpoed en de jacht om een markt voor de gemaakte producten te vinden in tijden van tegenspoed. Het gevolg was altijd prijsverlaging, daarna verlaging der loonen en voortbrenging van ininder waardige, inférieure qualiteit.

Wenschelijk is het ook waarborgen te geven aan de anndeelhouders der consolidaties, wier belangen door gebrek aan publiciteit gevaar loopen. De groote macht nan het bestuur dier ondernemingen gegeven, kan licht door de beheerders worden misbruikt ten eigen bate en dragen dan de aandeelhouders de geheele schade.

Waarschijnlijk zal de quaestie der groote consolidaties de aanstaande verkiezingen beheerschen. De tarief-quaestie heeft veel van haar vroeger belang verloren nu de industrie der Vereenigde Staten met die van Europa mededingt op de wereld-markt en in vele gevallen deze laatste. zelfs verdringt.

De zilver-quaestie kan ook moeilijk tot platform van eene politieke parij gebruikt worden nu er geen schaarschte van geldmiddelen is en de boer uit het Westen genoeg coutanten bezit oin zijne schulden langzamerhand had af te lossen. De oprichting der trusts echter is samengevallen met een sterke stijging in den prijs der bandelsartikelen. Natuurlijk hebben wij niet met oorzaak en gevolg te doen. De consolidatie der nijverheidsondernemingen en de prijsstijging der producten geschiedden onafhankelijk van elkaar. De eene gebeurtenis was een gevolg van den overvloed vau beschikbaar kapitaal, de andere 
van een groote intensiteit der vraag. Niet alleeu in de Vereenigde Staten, maar ook in Europa stegen de prijzen. Ook van artikelen, niet gecoutroleerd door eeu trust, steeg de prijs b. v. van hout en van steenkolen.

Deze feiten bewijzeu overtuigeud, dat niet alleen aan den invloed der "trusts" de prijsstijging is toe te schrijven. Natuurlijk zijn er vitzonderingen, die ook hier den regel bevestigen. Maar het valt niet gemakkelijk de ounadenkenden hiervan te overtuigen. In 1896 werd gezegd: haudel en nijverheid zijn in een toestand van depressie, de vrije aaumunting van zilver is geschorst, derhalve is de depressie een gevolg vau het verbod van zilveraanmunting. Een dergelijke onjuiste wijze van redeneeren, op een auder gebied overgebracht, zoude ook nu misschien instemıning verwerven. Men vindt dan ook in de tot heden openbaar gemaakte "platforms" herhaaldelijk de bewering, dat de "trusts" kunstmatig de prijzen der artikelen verhoogen.

Het gevaar voor eigenmachtige prijsverhooging ligt voornamelijk bij den "promotor." Indien de consolidaties op een roekelooze wijze overgekapitaliseerd zijn, kan de verleiding in ongunstige tijden sterk worden om datgene te doen, waarvan de trusts op dit oogenblik ten onrechte worden beschuldigd. Maar die poging om de prijzen te dwingen zoude mislukken en de ondernemingen zouden een duren prijs hebben te betalen voor hun willekeurig optreden.

Amsterdam.

W. C. Th. van der Sohalk. 